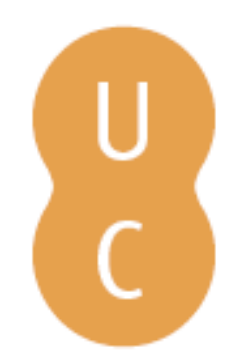

\title{
nommalina
}

\section{Self as future: vocational life-narratives and identity exploration in adolescence}

\author{
Autor(es): Jesus, Paulo R.
}

Publicado por: Imprensa da Universidade de Coimbra

URL

persistente: URI:http://hdl.handle.net/10316.2/38607

DOI: $\quad$ DOI:http://dx.doi.org/10.14195/978-989-26-0775-7_3

Accessed : $\quad$ 26-Apr-2023 14:40:12

A navegação consulta e descarregamento dos títulos inseridos nas Bibliotecas Digitais UC Digitalis, UC Pombalina e UC Impactum, pressupõem a aceitação plena e sem reservas dos Termos e Condições de Uso destas Bibliotecas Digitais, disponíveis em https://digitalis.uc.pt/pt-pt/termos.

Conforme exposto nos referidos Termos e Condições de Uso, o descarregamento de títulos de acesso restrito requer uma licença válida de autorização devendo o utilizador aceder ao(s) documento(s) a partir de um endereço de IP da instituição detentora da supramencionada licença.

Ao utilizador é apenas permitido o descarregamento para uso pessoal, pelo que o emprego do(s) título(s) descarregado(s) para outro fim, designadamente comercial, carece de autorização do respetivo autor ou editor da obra.

Na medida em que todas as obras da UC Digitalis se encontram protegidas pelo Código do Direito de Autor e Direitos Conexos e demais legislação aplicável, toda a cópia, parcial ou total, deste documento, nos casos em que é legalmente admitida, deverá conter ou fazer-se acompanhar por este aviso.

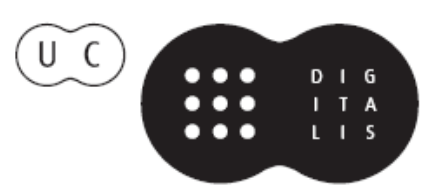




\section{INTERNATIONAL \\ STUDIES IN TIME \\ PERSPECTIVE}

MARIA PAULA PAIXÃO

JOSÉ TOMÁS DA SILVA

(COORD.)

VICTOR ORTUÑO

PEDRO CORDEIRO

(EDITORS)

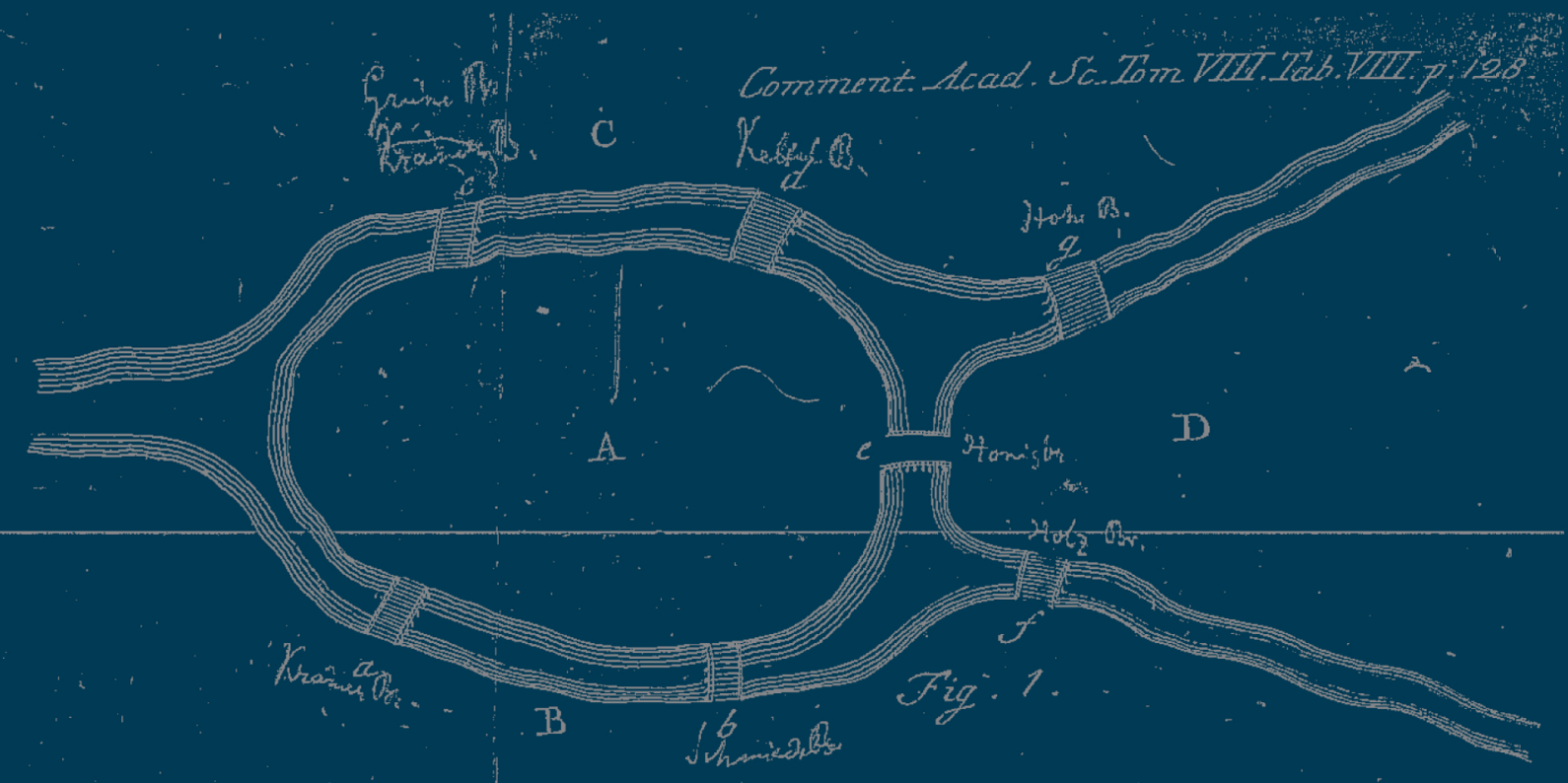

IMPRENSA DA

UNIVERSIDADE

DE COIMBRA

COIMBRA

UNIVERSITY

PRESS 


\title{
Chapter 3 \\ SELF AS FUTURE: VOCATIONAL LIFE-NARRATIVES AND IDENTITY EXPLORATION IN ADOLESCENCE
}

\author{
Paulo R. Jesus \\ University of Lisbon, Portugal \\ paulorenatus@gmail.com
}

\begin{abstract}
Aвstract: In this paper, we analyze the structuring role played by the subjective construction of future life-scenarios and storied self-images in the process of identity formation and vocational definition during adolescence. Our empirical data consist mainly of autobiographical narratives and oral discussion of moral and religious dilemmas collected through an adapted version of Dan P. McAdams Life Story Interview from a cross-sectional sample of 31 Portuguese adolescents. In addition to the narrative interview, the participants were invited to imagine and further elaborate on their desired future lives, thus describing and illustrating their conception of "good life" (or optimal psychosocial functioning). The results show that vocational and identity achievement motivation relies strongly on the dialectic and dialogical tension between contrasting grammars of prospective stories that enact the most likely possible selves and the most desirable selves or "imagined best selves". The mindscape of perceived or constructed future selfhood gives structure and dynamism to the subjects' self-exploration initiatives and supports the hypothesis that the meaningful activity of self-futuring is the master cognitive and emotional process in the generation of psychological time, existential direction and personal unity.
\end{abstract}

Keywords: possible selves, narrative identity, vocational exploration, at-risk youth, time perspective.

\section{INTRODUCTION}

\section{Narrative and Dialogical Identity}

Drawing from the concept of future "possible selves" (Markus \& Nurius, 1986), our research proposes that the generation of possible selves tends to occur predominantly in narrative mode and that idiosyncratic compounds of narrative possible selves embody imaginative self-simulations in which the meaningful content, attentional focus and emotional valence of one's own constructed futures translate into engagement in concrete courses of action. Furthermore, we assume in keeping with K. Gergen (1992, 1994, 2009) that self-narratives are webs of relationships and relational symbolic co-constructions crafting and expounding one's multi-being. From a temporal perspective (Nuttin \& Lens, 1985; Paixão, Abreu \& Lens, 2012; Zimbardo \& Boyd, 1999), life-scenarios on future possible selves offer an evaluative and interpretive key to read both past and present experience; to such an extent that we consider future possible selves, with their underlying feed-forward self-concern, to be the psychological origin of subjective time. Given the 
importance of abstract and hypothetical reasoning combined with an intensive focus on self-identity (McLean, 2005; McLean \& Pasupathi, 2010; Oyserman \& Fryberg, 2006), the self-futuring process gains momentum in the course of adolescence, and overlaps, at least partly, what Savickas et al. (2009) call "life designing", in the realm of vocational psychology.

We maintain as a general theoretical hypothesis that adolescent "identity crisis" (Erikson, 1968) and "ego-identity statuses" (Marcia, 1966) may be interpreted in narrative terms. The "identity crisis" might then be construed as a developmental task that consists in exploring the psychosocial meaning of future possible life stories, prior to making a stable commitment to a specific ideological and socio-behavioral selfnarrative system. The stage of moratorium is expected to display an unstable relationship of tentative identification between the narrators and the protagonists of future possible selves, corresponding to varied modes of self-experimentation and oscillating degrees of self-uncertainty that produce abundant episodic narrative fragments gradually unified in an overall net of storylines whose connections eventually give rise to a relatively crystallized narrative gestalt. Depending on the context that nurtures an adolescent's moratorium, a context more or less saturated with diverse symbols and relationships, the future-oriented self-storying process will encompass a greater or lesser range of narrative refraction, resulting in multiple narrators, characters and plots increasingly organized by an integrative and cohesive overarching metanarrative position. Using M. Bakhtin's (1981) metaphors to describe novels as ideologically "polyphonic" and sign-mediated selfhood as "dialogic consciousness", we hold that a proactive identity crisis, qua exploratory meaningconstruction, entails a relational organization of selfhood, creating a symbolic community of selves (Hermans \& Hermans-Konopka, 2010; Hermans \& Kempen, 1993). Identity foreclosure dodges crisis by yielding to a heteronomous, monological, self-system, prearranged by the internalized authority of an institution or significant other, thereby shielding the individual temporarily against any disturbing anxiety and uncertainty. As for identity diffusion, understood as the passive embodiment of identity crisis, very typical of at-risk youth, it may be represented as a specific type of narrative stasis marked by the lack of metanarrative capability to assess and balance the storied voices or ideological strands that compose one's polyphonic life-space. Therefore, self-diffusion is linked to a rather negative complex of future selves, and tends to fuel a broad indifference, if not hostility, towards mainstream institutions, values and norms. In such diffusedly un-engaged and relatively static identity texts, the experience of parallel relational encapsulation into closed and opposing spheres favors the formation of fragmented narrative voices that exclude and contradict each other, while their cohabitation in one's ecology remains unanalyzed and uncriticized, leading to implicit dissociation, alienation, conflict and muteness. The difference between moratorium and diffusion lies essentially in the presence or absence of a relational dynamism catalyzing the emergence of a critically self-analytic and selfwriting stance that works through multiplicity and contradiction. Indeed, in order for the narrative crisis to be a relational self-developmental process attaining identity achievement, the morphogenesis of novel narrative structures must be accompanied by a high degree of metanarrative or metasemiotic consciousness that questions the symbolic materials and interactions in which the sense of self and the criteria of self-intelligibility are formed and transformed. Now, moratorium-disorganized, identity-diffused and at-risk youth with low exploratory profiles are certainly deprived of metanarrative competence, and hence taken 
hostage by unbalanced interpretive mythbiographies and in-group rituals that celebrate a culture of tragic hedonism depicting life under the guise of an ephemeral play which permanently and nonchalantly puts the player at stake. In addition, the collapse of the future time perspective is intensified by "loss" taken as a self-interpretive framework. In fact, it appears that most life stories of diffused and at-risk youth comprise narratives of loss in which some experiences of suffering resist to full articulacy, carrying a hard core of haunting non-narratability, thus compressing time into a punctual here and now, place of refuge against the fear of repetition and paradoxical place of evasion without horizon. But it is the connection between interpersonal loss, dialogical poverty and present-centered media youth culture that produces sheer diffusion and vulnerability. For if, on the one hand, the traumatizing force of episodes of loss may leave the narrators temporarily speechless, unable to establish a creative alliance between others, agency and meaning; it must be acknowledged, on the other hand, that the loss is not absolutely unspeakable and disorganizing per se. Instead, narrative disorganization and paralysis proceed from a learned and shared style of self-interpretation that proliferates within certain peer groups and/or cross-generational family circles in which the narrative grammar of tragic decline, fatalistic chains of events, passive narrators and helpless characters informs the micro and macro-narratives in daily discursive interactions.

The narrative crisis that expresses an adolescent identity crisis responds to a disquieting cacophony of narrators and characters, often utterly irreconcilable (though it may be unrecognizable as in need of unification), and thus unable to be integrated into a common re-authoring process to articulate their qualitative discontinuities. The creation of a new life-story cycle involves a reorganization of episodic autobiographical memory by a learned narrative grammar that provides the form or gestalt for what can be recognized and valued as a good meaningful story by one's interlocutionary audience, namely family and peers, that is to say, one's dialogical community of live co-writing and co-reading.

\section{Method}

\section{Research paradigm and objectives}

The present research belongs to an intervention-oriented narrative research project to foster vocational definition in adolescents, embracing a qualitative, descriptive, idiographic and critical inquiry stance. In this context, we deem the analysis of narrative development to be crucial to understand not only the patterns and themes that pervade meaningconstruction strategies (McAdams, 1996, 2006a, 2006b) but also the sociocultural ecology that provides particular semiotic means and belief systems (Valsiner, 2007). The main practical goal aims at the promotion of narrative innovation (White, 2007; White $\&$ Epston, 1990) through the cognitive-emotional exploration of positive future possible selves. For the lack of exploration is expected to translate into a narrow and negative range of future narrative possible selves that block motivation for change and reinforce the repetition of constraining life scenarios.

In line with recent research on adolescent narrative development (Matsuba et al., 2010; Pasupathi \& Hoyt, 2009), we compare and assess different self-narrative styles with regard to vocational and identity development, in order to conceive new effective 
ways for stimulating and empowering adolescents. More specifically, this requires: a) relating narrative styles to personal ideological systems; b) placing narrative development in interpersonal and social context, with its practices and discourses; c) describing the conditions for the emergence and optimization of narrative innovation and re-authoring processes; d) micro-analyzing self-narrative change within and between subjects.

\section{Participants}

The subjects of this study $(\mathrm{N}=31$; Male $=16$, Female $=15)$ were students enrolled in two full-time vocational schools in Oporto, Portugal. Their ages range between 14 and 21 years, with an average age of 17 years, and they come from impoverished urban neighborhoods. An invitation to participate in a psychological study on "Youth and future life projects" was addressed to three different classes (i.e. Computer science, Civil construction, and Business). Students who volunteered took part in two sessions, one consisting of an individual interview and another of group discussion, lasting each of them about one and a half hours. The first session followed a narrative interview script, whereas the second session unfolded a lively group discussion on two topics: 1. the relationship between past and present in one's life story, and 2. the possibility or desire of future change. Both sessions were fully audiotaped and partly videotaped with the subjects' informed consent, then transcribed and submitted to qualitative data analysis.

\section{Instruments}

The interview was conducted in accordance with an adapted version of the Life Story Interview, originally developed by D. P. McAdams (1996), and performed with flexible constructivist sensitivity (Grant \& Johnston, 2006). The interview was designed to be able to identify themes and patterns that organize the life story, linking the interpretive selection of past experience (e.g. overall life-narrative, peak experiences, nadir experiences, turningpoints, good and bad moral decisions, positive and negative memories of childhood) with the imagination of future possible selves (rating the likelihood of an array of hoped and feared futures, and further elaborating on their conception of possible futures and "ideal future self"). Besides, another set of questions explored the semantic structure of the personal ideology of the subject (i.e. the system of religious, moral, social and political values), which included a series of open brief questions (e.g. "Are you a religious person? If so, how do you define God?") as well as two dilemmas to be discussed and solved, a version of Heinz moral dilemma (Kohlberg, 1981) and a version of Paul religious dilemma (Oser \& Gmünder, 1988). The classical technique of counter-suggestion was used to probe the stability of cognitive structures.

\section{Results}

The qualitative data analysis attempts to show how the representation of future possible selves is related to the semantic structure of their life stories and ideological systems. In 
so doing, we may chart a dynamic field of possible self-narrations in which subjective singularities are embedded, though producing a virtually infinite spectrum of sui generis narrative forms. The subjects move between narratives of loss and narratives of growth which express an ideological essential tension, whose extreme opposite poles are the denial and affirmation of values, linked to doubt and hope regarding future possibilities.

\section{Narratives of loss: a futureless grammar and a skeptical ideology}

Life-stories seem futureless when they represent the past under the form of tragedy and steady decline: the negativity of the nadir experience obliterates the significance of the peak experience, and the turning-point indicates a qualitative and lasting change for the worse. Tragic self-narratives do imagine a future line but this imagination revolves around the conviction of the high likelihood of script repetition, punctuated by tragic chains of events to be continued, and represented with inflexible cognitive passivity. The subjects who insisted on script repetition as their most likely possible future interpreted episodes of interpersonal loss as utterly destructive, central and irreversible, evoking namely the premature death of or separation from a parent, or episodes of neglect and abuse by family members. The belief in agency is superseded by the perception of external control exerted by an anonymous force driven by destructive randomness. Loss is then both a self-interpretive narrative category and an ideological metanarrative that implies self-loss, as well as the belief in circular time and in powerless volition. Paradoxically, the adoption and cultivation of a victimized identity become also a form of power in interpersonal relationships, justifying the claim for exceptional treatment, although moderated by the idea that a tragic life exposes a self engulfed by pure nonsense and helplessness. Therefore, the tragic victim demands understanding and refuses the very possibility of being fully understood by any interlocutor, regardless of their ability for empathy or insight. Events, not actions, are the efficient force of these stories of loss, which are essentially mutilated stories in that they lack narrators and characters who are capable of being the centers of narrative gravity. In other words, there is no perception of narrative self-efficacy. Instead, the meaning-making process is dominated by the belief of dispossession and heteronomy, intensified by an ego-offensive attributional style (the tragedy being told as commanded by external, unstable and uncontrollable forces).

The passivity of these tragic selves confirms their living tragedy by converting the openness of the possible futures into mere cyclical variations of their narrative reconstructions of the past. The negativity of the past is articulated with the closure of the future, and, is reinforced by a skeptical ideology that endorses a nihilistic axiological outlook (as their typical statements aptly put it: "I do not believe in anything. God, Fate, Luck, Love... childish stuff... nothing is true, nothing is worth believing." [M18] "All living things are going to die. That's the bright future of everything. In a sense, we were already dead before birth. Before birth and after death are the same thing. This interval called life is a nonsense that one must enjoy as much as possible. [laughs]" [F17]). This nihilism is affirmed with full confidence as the wisest last word on the meaning of life; it becomes then a dogmatic belief, impervious to criticism, and its cognitive rigidity forsakes all effortful goal-setting processes, in favor of present-centered hedonism. 


\section{Narratives of growth: a future-centered grammar and an ideology of hope}

As long as the meaning of the past is negatively determined, the future cannot bring a positive discontinuity. So the imaginative invention of the future entails the fluid indeterminacy or plasticity of the past, that is, a possible redescription of the past in which the idiom of growth and learning jeopardizes the constraining texture of the idiom of loss. Further, true narrative innovation and strong agency do not emerge without a critical deconstruction of script repetition and a motivational investment towards novelty and spontaneity. However, this does not imply any denial of past suffering or disconnection with lost significant others and replacement of attachment figures (as suggested by the psychoanalytic notion of mourning as "decatexis"). Instead, the commitment to selfinnovation, which opens the possibility of future, proposes a reinterpretation of the subject's place in the nadir experiences, adopting the perspective of a romantic Bildungsroman, a story where past and present ordeals are the necessary condition for self-knowledge, selfimprovement and, eventually, self-actualization. In the narratives of growth, the nadir experiences are located in the self-generative and self-transformative process of peak experiences. "Loss" is here nullified as such, for it means an incremental gain, a dynamic resource for narrative progression.

The invention of a self-transcending future relies on the unification of subjective temporal experience under a globally positive self-appraisal, reconciling "death" with "life" and interweaving a creative thread of meaning that gives an ascending existential direction to all enterprises and ordeals. True, the ideology of hope that accompanies the narratives of growth acknowledges the temptation of skepticism and nihilism when coping with frustrating outcomes ("I do not know if God exists, especially when I feel on the brink of collapse, but I think I must believe and act as if God or Something existed, otherwise... what for?" [M16]) but refuses all dogmatism to embrace a higher level of transcendental ignorance and humility ("God may exist or not. It's a possibility, an Unknown. My mantra is Life is a spell nobody can tell. Instead of believing, one may hope. That's all. Peace.” [F16]). The hope of narrative self-efficacy that stimulates vocational and ego-identity exploration is generated within the large ethical framework affirming the possibility of future.

\section{Discussion and Conclusions}

\section{Multiple metanarrative principles: unconscious spectrum of opposite fidelities}

Life-narratives are organized by ideological, axiological, structures and processes that we term metanarrative (though it may also qualify an individual's awareness on the conditions of their self-narrative productions). "Loss and skepticism" and "growth and hope" are the values that shape the two main metanarrative types in competition among our subjects. They provide the cultural internalized normative expectations concerning the intelligibility of specific lived experience as a recognizable "story", and therefore they guide the selective and interpretive process of sequencing life-events and connecting them meaningfully. However, although subjects demonstrate clear metanarrative preferences that proceed from their ecologies of development, those preferences are permanently challenged by contrastive metanarrative schemata because the ecologies are ideologically polyphonic 
spaces that do not allow one to engage in absolute fidelities. Hence, selfhood becomes a dialogical and dialectical field organized by dominant ideal types of self-interpretation and self-narration. If such multivocality may destabilize the cognitive comfort of selfcongruence, it constitutes an enriching resource that prevents cognitive rigidity and invites one to take diverse cross-paradigmatic perspectives, thereby increasing the complexity and flexibility of meaning-construction. That is why, to our mind, the analysis of metanarrative conflicts deserves to occupy a central focus in narrative research.

Vocational development acquires full psychological and psychosocial significance when considered as embedded in the developmental process of identity formation, in which the charting of the future life-space constitutes the hardcore of the motivational self-concern that is conveyed by the very metaphor of "vocation" (a unique inner voice calling for being). Our main conclusion states that the relational construction of one's possible futures comprises a selective rewriting of rational-emotional self-interpretations and socio-moral self-assessments of remembered and imagined life stories. Therefore, the future is not merely another temporal dimension: it is the imaginative virtuality that institutes the teleological unity of all subjective time and in which all other temporal dimensions originate. In other words, the self-futuring activity or the self-projective imagination is essentially polychronic and panchronic in the sense that all subjective times and their subjective wholeness are co-present, though possibly with sharp inner dissonances or even formal contradictions. As a conscious and agential temporal process, selfhood emerges from that self-futuring imagination, undergoing permanent qualitative change and opening up the idiosyncratic spectrum of one's "multi-being" that reveals the capability of their relational resources to respond to significant situational demands. Moreover, the shape of one's identity trajectories with the creation of possible, real and ideal selves reflects the appropriation of semiotic resources in certain socio-cultural ecologies. It hence follows that the dialectic tensions between the perception of likelihood and desirability of future selves proceed from internalized dialogical conflicts whose voices represent contrary life-story grammars or axiological metanarratives or Weltanschauungen. To sum up, once a process of subjective meaning-construction is at work, it is necessarily anchored on the semiotic saturation of experience, and, by the same token, it proves that developmental constructivism implies social constructionism.

\section{REFERENCES}

Bakhtin, M. (1981). The dialogic imagination. Austin: University of Texas Press.

Erikson E. (1968). Identity: Youth and crisis. New York: Norton.

Gergen, K. J. (1992). The saturated self: Dilemmas of identity in contemporary life. New York: Basic Books.

Gergen, K. J. (1994). Relationships and realities: Soundings in social construction. Cambridge, MA: Harvard University Press.

Gergen, K. J. (2009). Relational being: Beyond self and community. Oxford: Oxford University Press.

Grant, E., \& Johnston, J. (2006). Career narratives. In M. McMahon \& W. Patton (Eds.), Career counseling: Constructivist approaches (pp. 110-122). London: Routledge.

Hermans, H. \& Hermans-Konopka, A. (2010). Dialogical Self Theory: Positioning and counterpositioning in a globalizing society. Cambridge: Cambridge University Press. 
Hermans, H. J. \& Kempen, H. J. (1993). The dialogical self: Meaning as movement. San Diego: Academic Press.

Kohlberg, L. (1981). Essays on Moral Development. Vol. I: The Philosophy of Moral Development. San Francisco, CA: Harper \& Row.

Marcia, J. E. (1966). Development and validation of ego identity status. Journal of Personality and Social Psychology, 3, 551-558.

Markus, H., \& Nurius, P. (1986). Possible selves. American Psychologist, 41, 954-69.

Matsuba, M. K. et al. (2010). Re-storying the lives of at-risk youth: A case study approach. In K. McLean \& M. Pasupathi (Eds.), Narrative development in adolescence: Creating the storied self (pp.131-149). New York: Springer.

McAdams, D. P. (1996). The stories we live by: Personal myths and the making of the self. New York: Guilford.

McAdams, D. P. (2006a). The person: An integrated introduction to personality psychology (4th ed.). New York: John Wiley \& Sons.

McAdams, D. P. (2006b). The redemptive self: Stories Americans live by. New York: Oxford University Press.

McLean, K. (2005). Late adolescent identity development: Narrative meaning making and memory telling. Developmental Psychology, 41, 4, 683-691.

Nuttin, J., \& Lens, W. (1985). Future time perspective and motivation: Theory and research method. Leuven \& Hillsdale, NJ: Leuven University Press \& Erlbaum.

Oser, F. \& Gmünder, P. (1988). Der Mensch: Stufen seiner religiösen Entwicklung. Gütersloh: Gütersloher Verlagshaus.

Oyserman, D., \& Fryberg, S. (2006). The possible selves of diverse adolescents: Content and function across gender, race and national origin. In C. Dunkel \& J. Kerpelman (Eds.), Possible Selves: Theory, Research, and Applications (pp. 17-39). New York: Nova Science.

Paixão, M. P., Abreu, M. V., \& Lens, W. (2012). Motivation, future time perspective and vocational planning behavior. In D. A. Leontiev (Ed.), Motivation, Consciousness and Self-Regulation (pp. 41-63). New York: Nova Science.

Pasupathi, M., \& Hoyt, T. (2009). The development of narrative identity in late adolescence and emergent adulthood: The continued importance of listeners. Developmental Psychology, 45, 2, 558-574.

SAvicKas, M. et al. (2009). Life designing: A paradigm for career construction in the 21st century. Journal of Vocational Behavior, 75, 3, 239-250.

VAlsiner, J. (2007). Culture in Minds and Societies: Foundations of Cultural Psychology. London: Sage.

White, M. \& Epston, D. (1990). Narrative means to therapeutic ends. NY: Norton.

White, M. (2007). Maps of narrative practice. New York: Norton.

Zimbardo, P., \& Boyd, J. (1999). Putting time in perspective: A valid, reliable, individual-differences metric. Journal of Personality and Social Psychology, 77, 6, 1271-1288. 